\title{
The Development of Students Worksheets for Constructing Knowledge of the Fundamental Laws of Chemistry
}

\author{
Abudarin \\ Department of Chemistry Education \\ Universitas Palangkaraya \\ Palangkaraya, Indonesia \\ darin@chem.upr.ac.id
}

\begin{abstract}
It is a crucial issue that the result of TIMSS in 2011 placed Indonesia in the $38^{\text {th }}$ rank of the 42 countries for mathematics and in $40^{\text {th }}$ rank of the 42 countries for science. These facts indicate that the students' skills in reasoning is still poor since the understanding of math and science is a reflection of the ability to reasoning. The new paradigm of learning requires students to be able to construct their own knowledge by inductive or deductive reasoning. In this case, the students need some guidance so that they are able to acquire the knowledge they need to understand. This research aims to develop learning guidance for constructing the knowledge of the fundamental laws of chemistry by inductive reasoning based on the presented data. The development of worksheets of this study was conducted using 4-D model of Thiagarajan. The results showed that the developed worksheet in this study is categorized as excellent which had 0.84 of Aiken's average validity coefficient. Therefore, the worksheets were easy to understand, easy to implement, and were able to guide the students in constructing the knowledge of chemistry. The result of try-out displayed that the effectiveness of the worksheets developed was excellent of $84.37 \%$.
\end{abstract}

Keywords—student worksheets; inductive reasoning; chemistry

\section{INTRODUCTION}

The results of the previous studies showed that the majority of chemistry concepts in Central Kalimantan are understood by the students through the teacher's explanation. In fact, there are only few students acquire the knowledge by their own thinking or reasoning process. This situation has an impact on the poor ability of students in reasoning. The study of Trends in International Mathematics and Science Study (TIMSS) in 2011 placed Indonesia in the $38^{\text {th }}$ rank of the 42 countries for mathematics skill and in $40^{\text {th }}$ rank of the 42 countries for science skill. These facts indicate that the students' skills in reasoning is still poor since the understanding of math and science is a reflection of the ability to reasoning. This condition can also be interpreted that the learning which has been done has not been able to optimally develop students' reasoning skill.

Learning in the perspective of constructivist theory is a process in which the students are mentally active to construct new knowledge based on the cognitive structure already mastered. Reference [3] stated that constructivist learning approach is the process of developing new knowledge in the students' cognitive structure based on their own experiences. Constructivist learning approach puts an emphasis on students' active role in gaining understanding and interpretation of the information and events they experienced. This approach includes creating the awareness of students related to the current concepts, creating a broad mental space including multiple conceptual parts, and providing the adaptation of the new information to the previous knowledge through constant contextual communication and harmonization. This model is a promoting model for the students to take into account the importance of the concepts as mental elements, to develop not only positive attitudes towards science and learning, but also towards scientific process skills in order to increase the their achievements [5]. Based on the perspective of constructivist, the task of a teacher is to create a learning environment that is often referred to "scenario of problem" that reflects their authentic or real learning experience that can be applied in a real situation.

One method that is very relevant to the constructivist view of learning is a method of discovery learning developed by Jerome Bruner. In the process of learning, the ability of students to construct new knowledge can be optimally developed through discovery learning. According to Bruner [15], in the learning process students should actively use the concepts or principles they have mastered and conduct investigations or experiments to discover the concepts and principles of a new one. Methods of the invention provide a positive impact on learning outcomes for the students to participate actively to gain experience and learn to find the concept of interacting with the environment [4].

The process of constructing new knowledge in learning follows the framework of the invention (inductive and deductive reasoning) that meets the characteristics of the substances being studied. However, inductive reasoning is generally preferred in scientific work. Inductive reasoning, according to [11], is the process of thinking in our sense of 
knowledge dealing with the events or things that are concrete and specific to infer more general knowledge. Reference [7] mentioned that the development of conceptual knowledge can be acquired through the relations among information. The process of relating occurs among the information stored in the memory or between the existing knowledge and new information.

Taba [10] introduced a learning strategy that is based on inductive thinking. The inductive learning strategies is also developed on the basis of the concept of students' mental processes by giving attention to how the students handle information and get it done. Inductive learning strategy is a strategy designed to help students develop higher level thinking skills and creative through observation, comparing, finding patterns, and generalizing [8]. Reference [9] stated that the inductive learning model relies on information processing through the process of thinking inductively.

The model of inductive thinking is developed on the basis of some postulates as follows: (1) the ability to think can be taught; (2) thinking is an active transaction between the individual and the data; (3) the thinking process is a sequence of steps that is regular (lawful). In the process of learning and teaching activities, materials are a means for students to develop certain cognitive operations. In these activities, students learn to organize facts into a system of concepts such as: (a) relating the data obtained mutually to each other and make conclusions based on those relations; (b) drawing conclusions based on the facts that have been learned in order to state a hypothesis; and (c) predicting and explaining a particular phenomenon.

Inductive learning strategy is oriented to learning information processing. The steps of inductive strategy includes: (1) the establishment of the concept (recording, classifying, and naming) of the works to be appreciated; (2) analysis of concepts (interpreting, comparing, and generalizing); (3) application of the principles (analyzing a new problem, making hypotheses, answering the hypothesis, and checking the hypothesis) can be terminated through the creation of new works. Some studies showed that an inductive strategy, model, or approach provides better learning outcomes at various levels of education. The research result [12] showed that the average scores obtained by science students who learned using integrative-based inductive learning model were higher than the average scores obtained by science students who learned using conventional learning. Reference [13], based on the research results, suggest that there are significant differences due to the effects of the application of inductive learning models using animation macro media flash on seventh grade students' learning outcomes of the seventh grade at SMP Negeri 1 Pagaran on the materials of the heat. Inductive approach referring to constructivism in learning is able to optimally develop the power of reason, the ability of students to think logically, critically, and creatively [14].

Chemistry is a science that is developed from empirical facts through scientific processes. Scientific processes in the development of chemistry largely involve inductive thinking process; therefore, inductive strategy is the right choice in studying chemistry. In this perspective, chemistry should be used as a vehicle to train the students' ability to think.

In inductive learning activities, the students are required and trained to make reason or think to be able to find the knowledge they have mastered. Of course, this is not easy for students who have been accustomed to receive knowledge from the teacher's explanation. In this case, the students need help in the form of guidance, counseling, or referrals to think that they are able to assemble the facts, concepts or principles into new knowledge that must be mastered. Therefore, the real success is highly dependent on the model of inductive strategies given to the students. The model includes guidance, counseling, or direction of thinking that can be packaged in the form of students' worksheets. The worksheets contain tasks that must be done by the students.

This research has developed a learning guidance (in the form of worksheets) with inductive line of reasoning that "enables" the students to create reasoning in order to find their own knowledge of chemistry to be mastered. In this study, the substance of fundamental laws of Chemistry" was chosen as a vehicle to develop inductive reasoning and thinking skills: (a) knowledge of the fundamental laws of chemistry in the form of concepts and principles developed from empirical facts; (b) the basic knowledge which is a prerequisite for all quantitative chemical knowledge.

This research is a research and development study having a common goal to develop worksheets based on inductive reasoning (inductive worksheets) based on the data presented in the fundamental laws of chemistry in high school which includes: (1) Law of Conservation of Mass; (2) Law of Definite Proportions; (3) Law of Multiple Proportions; (4) Law of Volume Proportions; and (5) Avogadro's Law.

Specific goals to be achieved are: (1) to test the feasibility of the product (inductive worksheets) on aspects of readability, the potential of enforceability and expediency; (2) to determine the ability of students in constructing knowledge about the fundamental laws of chemistry.

The practical utility of these results is that the worksheets developed inductively are expected to be used as a learning guidance that enables students to construct their own knowledge of chemistry to be mastered. The results of this study are also expected to provide theoretical benefits to enrich the theoretical and empirical studies on learning strategies oriented to the development of student abilities in constructing knowledge independently.

\section{METHOD}

This is a research and development. The subject of this research is the development of products in the form of inductive worksheets. The worksheets were designed by implementing inductive reasoning to gain new knowledge. The assessment of feasibility on the worksheets developed involved experts and teachers as potential users.

This research was conducted in two stages. The first stage of the research was to develop a model of the invention learning in the form of student worksheet for being used in the 
teaching of chemistry in high schools. The procedure of the development adapted the 4-D development model of Thiagarajan. The development of the model consisted of four stages namely defining or restricting, designing, developing, and disseminating [15].

The stage of defining began with an analysis of the curriculum, analysis of learners and learning problems, and analysis of learning materials. At the design stage, the draft of the worksheets was created. It was called draft-1. The worksheet drafting refers to the common used format, while the substance of the coverage refers to the results of the analysis of curriculum and learning materials. At the stage of developing, assessment on worksheets feasibility was carried out using expert judgment through expert validation and tryout. The initial step of assessing was the validation and revision of the earlier draft (draft-1) by the experts. The assessment of experts was carried out to test the feasibility of draft-1 in terms of (1) the legibility, (2) the applicability, and (3) the utility. The results of the assessment and corrections of experts were then used to revise the draft-1. The revised draft1 was herein after referred to draft- 2 and it was ready for pilottested on the try-out. The try-out was conducted on the teaching and learning process of chemistry at SMAN 4 Palangkaraya.

The data of the worksheets feasibility including readability, applicability, and utility were collected using questionnaires distributed to the experts and potential users (teachers) of chemistry in high schools. The ability of students to acquire the knowledge of chemistry through inductive reasoning was revealed from the try-out document of students' worksheets. The scores of the experts on the assessment of worksheet feasibility using five-scale parameter were tabulated and calculated to get the average scores. Determining the content validity coefficient was using Aiken's formula as in [1]. Aiken's statistics can be written as follows:

$$
\mathrm{V}=\Sigma \mathrm{s} /\{\mathrm{n}(\mathrm{c}-1)
$$

note: $\mathrm{V}=$ coefficient content validity

$\mathrm{s}=\mathrm{r}-$ Io

Io $=$ lowest judging scores

$\mathrm{C}=$ the highest assessment score

$\mathrm{r}=$ scores given by assessors

$\mathrm{n}=$ number of experts

To determine the ability of the students in constructing the knowledge, the documents of the students worksheets were scored using the scoring guidelines already prepared. The scores were transformed into a value range of 0 to 100 and were then calculated on the average and subsequently were converted to a qualitative five-scale catagory i.e. from "very poor" to "very good".

\section{RESULTS AND DISCUSSION}

\section{A. Developing the Worksheets}

The worksheets developed in this study were intended to guide the students' activities in finding the knowledge of the fundamental laws of chemistry that they have to understand through inductive reasoning. The worksheets are designed so that the students are able to reason inductively to find knowledge about the fundamental laws of chemistry. The fundamental laws of chemistry learned on the tenth grade of high school including (1) the laws of mass eternity; (2) the laws of definite proportions; (3) the laws of multiple proportions; (4) the laws of volume comparison; and (5) Avogadro's law.

Learning activities through inductive reasoning require data or information (which is specific) that must be processed to draw general conclusions. In the developed worksheets, the data or information required has been presented on the worksheets. The students needed to process the data through inductive reasoning to acquire knowledge about the fundamental laws of chemistry. It is based on the consideration that most of the empirical data needed by the students can not be obtained through observation due to the lack of facilities in the schools.

\section{B. Assessing the Worksheets}

The worksheets developed in this study were assessed using expert judgment to obtain the information of legibility, applicability, and utility. Those aspects were assessed based on the expert judgment. The data of legibility, applicability, and utility were presented as follows. The assessment was carried out by eight experts including teachers as potential users.

\section{1) The Worksheets legibility}

The data of worksheet legibility were collected using questionnaires with five aspects of assessment: (1) the level of legibility based on the size of the letters (fonts) used, (2) the level of the legibility of words used, (3) the legibility of the content/message, (4) The level of legibility of pictures or illustrations; and (5) the hierarchy and systematic writing. The average scores of expert assessment on the worksheets legibility is presented in Table I.

TABLE I. THE AVERAGE SCORE OF COEFFICIENT VALIDITY AND READABILITY ON THE WORKSHEETS

\begin{tabular}{|l|c|c|}
\hline \multicolumn{1}{|c|}{$\begin{array}{c}\text { Statements Regarding the Assessed } \\
\text { Aspect }\end{array}$} & \multicolumn{1}{c|}{$\begin{array}{c}\text { Average } \\
\text { Score }\end{array}$} & $\begin{array}{c}\text { Aiken's Validity } \\
\text { Coefficients }\end{array}$ \\
\hline The font can be read well. & 4.80 & 0.91 \\
\hline $\begin{array}{l}\text { The words or terms used can be easily } \\
\text { understood. }\end{array}$ & $4: 20$ & 0.85 \\
\hline $\begin{array}{l}\text { The content/message of every } \\
\text { sentence is understandable. }\end{array}$ & 4.80 & 0.80 \\
\hline $\begin{array}{l}\text { The pictures or illustrations can be } \\
\text { easily understood. }\end{array}$ & $4: 00$ & 0.85 \\
\hline $\begin{array}{l}\text { The step of learning activities is } \\
\text { arranged and understandable. }\end{array}$ & $4: 20$ & 0.79 \\
\hline $\begin{array}{l}\text { The average score of the } \\
\text { worksheets legibility. }\end{array}$ & $4: 40$ & 0.84 \\
\hline
\end{tabular}


It appears from Table I that the Aiken's validity coefficient for worksheet legibility was 0.84 in "very good" category. Thus, it can be stated that the worksheets are readible, understandable, and sistematic-arranged.

\section{2) The Worksheet Applicability}

The level of applicability of learning activities contained in the worksheets was assessed in four aspects are (1) the ease of carrying out instructions; (2) the adequacy of the data presented to the inference; (3) the applicability of strategy to their invention; (4) the ability of the students to construct knowledge; and (5) the adequacy of the time allocation. The data of the expert assessment are presented in Table II.

TABLE II. VALIDITY COEFFICIENT AND AVERAGE SCORE OF WORKSHEET APPLICABILITY

\begin{tabular}{|l|c|c|}
\hline \multicolumn{1}{|c|}{ The Assessed Aspects } & $\begin{array}{c}\text { Average } \\
\text { Score }\end{array}$ & $\begin{array}{c}\text { Aiken's Validity } \\
\text { Coefficients }\end{array}$ \\
\hline $\begin{array}{l}\text { Instructions on the worksheet } \\
\text { were easily implemented by } \\
\text { students. }\end{array}$ & 4.80 & 0.90 \\
\hline $\begin{array}{l}\text { The information presented on the } \\
\text { worksheets is sufficient to } \\
\text { perform the inference. }\end{array}$ & 4.20 & 0.88 \\
\hline $\begin{array}{l}\text { The worksheets make teachers } \\
\text { feel ease to implement the } \\
\text { strategies of discovery learning. }\end{array}$ & 4.20 & 0.87 \\
\hline $\begin{array}{l}\text { The activities on the worksheet } \\
\text { motivate the students to obtain } \\
\text { knowledge about the fundamental } \\
\text { laws of chemistry. }\end{array}$ & 3.80 & 0.82 \\
\hline $\begin{array}{l}\text { The time allocation provided is } \\
\text { sufficient to perform the learning } \\
\text { activities. }\end{array}$ & 4,00 & 0.80 \\
\hline \multicolumn{1}{|c|}{ Average Score } & 4.20 & 0.86 \\
\hline
\end{tabular}

The worksheets developed from the aspects of applicability have the Aiken's validity coefficient of 0.86 which is "very good" category. This means that these worksheets can be used successfully in teaching chemistry in schools.

\section{3) Worksheet Utility}

The utility of the worksheet was assessed by five aspects namely (1) the benefits of worksheets for teachers in implementing the concept of discovery learning; (2) the effectiveness of the worksheet in guiding students to discover concepts/principles of chemistry; (3) the opportunity for the students to find the concept/principles of chemistry; (4) the potential of internalizing the concepts/principles of chemistry that the students obtained through inductive reasoning using the worksheets; and (5) the potential in developing thinking skills. The average score of respondents' assessment on the aspects is presented in Table III.
TABLE III. VALIDITY COEFFICIENT AND AVERAGE SCORE OF WORKSHEET UTILITY

\begin{tabular}{|c|c|c|}
\hline The Assessed Aspects & $\begin{array}{l}\text { Average } \\
\text { Score }\end{array}$ & $\begin{array}{c}\text { Aiken's validity } \\
\text { coefficients }\end{array}$ \\
\hline $\begin{array}{l}\text { The instructions on the worksheets } \\
\text { are easily implemented by students. }\end{array}$ & 4.80 & 0.90 \\
\hline $\begin{array}{l}\text { The data information presented on } \\
\text { the worksheet is sufficient to } \\
\text { perform the inferences. }\end{array}$ & 4.20 & 0.88 \\
\hline $\begin{array}{l}\text { The teachers can implement } \\
\text { discovery learning using the } \\
\text { worksheets. }\end{array}$ & 4.20 & 0.87 \\
\hline $\begin{array}{l}\text { The students can do the learning } \\
\text { activities the knowledge of the } \\
\text { fundamental laws of chemistry. }\end{array}$ & 3.80 & 0.82 \\
\hline $\begin{array}{l}\text { The time allocation is sufficient to } \\
\text { perform the learning activities } \\
\text { using the worksheets. }\end{array}$ & 4,00 & 0.80 \\
\hline Average Score & 4.20 & 0.86 \\
\hline
\end{tabular}

Table III shows that the worksheets developed have Aiken's validity coefficient of 0.83 which is on "very good" category. Thus, it can be said that the worksheets can guide students to construct the knowledge of the fundamental laws of chemistry. Aiken's validity coefficient of readability, applicability, and utility show that students' worksheets are very feasible to implement in the learning process.

\section{Ability of Students to Construct the Knowledge}

The worksheets developed have been tested by the tryout conducted at SMAN 4 Palangkaraya. The try-out was intended to determine the effectiveness of the worksheets in terms of the ability of students to construct the knowledge of the fundamental laws of chemistry. In this case, the effectiveness was assessed from the average percentage of knowledge that can be constructed by students. The greater the percentage of the knowledge constructed by the students, the greater the effectiveness of the worksheets are. The ability of the students to construct the knowledge of chemistry was based on the success of students in acquiring the right conclusions in each topic of learning. The data is presented in Table IV.

TABLE IV. ABILITY OF STUDENTS TO CONSTRUCT THE KNOWLEDGE OF THE FUNDAMENTAL LAWS OF CHEMISTRY USING THE WORKSHEETS

\begin{tabular}{|c|c|c|}
\hline The Knowledge of Chemistry & $\begin{array}{c}\text { Average Students } \\
\text { Ability (\%) }\end{array}$ & Category \\
\hline 1. Law of Conservation of Mass & 90.62 & Very good \\
\hline 2. Law of Definite Proportions & 90.62 & Very good \\
\hline 3. Law of Multiple Proportions & 71.85 & Good \\
\hline 4. Law of Volume Proportions & 87.50 & Very good \\
\hline 5. Avogadro's law & 81.25 & Very good \\
\hline Average & 84.37 & Very good \\
\hline
\end{tabular}

The results of try-out show that the success of the students in constructing the knowledge of the fundamental laws of chemistry using the worksheets is in excellent level with the score of $84.37 \%$. This means that by using the worksheets the 
students are able to construct $83.47 \%$ of their own knowledge about the fundamental laws of chemistry. This result is in line with [2] which was stated that the constructive approach was more successful than traditional teaching method. The successful of interactive direct teaching based on constructivist learning attributed to the students' positive attitude associated with the conceptualization and the creation of three-dimensional mental space of the knowledge [6].

\section{CONCLUSION}

The experts judgment scored that the worksheets developed in this research are suitable to be used because (a) it is easy to read, easy to understand, and systematically compiled; (b) it is easily implemented in learning; (c) it can guide the students to construct the knowledge of the fundamental laws of chemistry that must be mastered. The results of the try-out showed that the effectiveness of the worksheets in guiding students to construct the knowledge of the fundamental laws of chemistry is excellent of $84.37 \%$. Since the worksheets are able to guide the students to construct knowledge of chemistry that they have to master, the teachers are suggested to develop effective worksheets to guide students to construct their own knowledge of chemistry and to develop students' ability to reasoning. The worksheets can be used in learning activities as the guide for the students to construct knowledge, particularly the knowledge of a concept or principle which is developed on facts.

\section{REFERENCES}

[1] S. Azwar, "Reliabilitas dan Validitas," Yogyakarta: Pustaka Pelajar, 2015.

[2] Y. Bogar, S. Kalender, M. Sarikaya, "The effects of constructive learning method on students' academic achievement, retention of knowledge, gender and attitudes towards science course in 'matter of structure and characteristics' unit," Procedia -Social and Behavioral Sciences 46, 2012, 1766 - 1770 .

[3] E. P. Daryanti, Y. Rinato, S. Dwiastuti, "Peningkatan kemampuan penalaran ilmiah melalui model pembelajaran inkuiri terbimbing pada materi sistem pernafasan manusia," Jurnal Pendidikan Matematika dan Sains. (2) 3, 2015, 163-168.

[4] E. M. Furtak, T. Seidel, H. Iverson, D. Briggs, "Experimental and quasi experimental studied of inquiry-based science teaching: A metaanalysis," American Educational Research Assiciation \& SAGE: Review of Educational Research, 82(3), 2012, 300-329.

[5] A. Gurses, K. Gunes, T. Dalga, C. Dogar, "A design practice for interactive- direct teaching based onconstructivist learning (IDTBCL): boiling and evaporation," Procedia - Social and Behavioral Sciences $197,2015,2377-2383$

[6] A. Gurses, S. Demiray, C. Doğar, "A Design practice for interactivedirect teaching based on constructivist learning (IDTBCL): dissolution and solutions," Procedia - Social and Behavioral Sciences 191, 2015, $44-49$.

[7] J. Hiebert, "Conceptual And Procedural Knowledge: The Case Of Mathematics". London: Lawrence Erbaum Associates Publishers, 1986.

[8] M. Huda, "Model-model Pengajaran dan Pembelajaran," Yogyakarta: Pustaka Pelajar, 2014.

[9] B. Joyce and Weil, "Models of Teaching," Prentice Hall. USA, 2009.

[10] B. Joyce, M. Weil, and Calhoun, "Models of Teaching (6 th ed)," USA: A Pearson Education Company, 2000.
[11] Poespoprodjo and Gilarso, "Logika Ilmu Menalar. Dasar-Dasar Berpikir Tertib, Logis, Kritis, Analitis, Dialektis," Bandung: Pustaka Grafika, 2009.

[12] I. A. A. L. Putri, K. Ardana, N. N. Ganing, "Pengaruh model pembelajaran induktif berbasis integratif terhadap hasil belajar IPA siswa kelas V semester I Sekolah Dasar Gugus R.A Kartini," Jurnal Mimbar PGSD (1)2, 2014.

[13] L. Sulastri and E. M. Ginting, "Pengaruh model pembelajaran induktif dengan menggunakan animasi macromedia flash terhadap hasil belajar pada materi kalor siswa kelas VII SMP Negeri 1 Pagaran T.A. 2013/2014," Jurnal Inpafi 3(2), 2014, 172-181

[14] Sulistyani, "Pendekatan induktif dalam pembelajaran kimia beracuan konstruktivisme untuk membentuk pemikiran kritis, kreatif, dan berkarakter," Prosiding Seminar Nasional Kimia dan Pendidikan Kimia. Jurusan Kimia FMIPA Universitas Negeri Yogyakarta, 2010.

[15] Trianto, "Mendesain Pembelajaran Inovatif Progresif. Konsep Landasan Dan Implementasinya Pada Kurikulum Tingkat Satuan Pendidikan,” Jakarta: Kencana, 2009. 